\title{
The Effects of Hormonotherapy Following Concomitant Use of Trastuzumab and Radiation Therapy on Late Skin Toxicity
}

\author{
Yasemin B. CIHAN ${ }^{1}$, Vedat ARSAV ${ }^{2}$ \\ ${ }^{1}$ Kayseri Training and Research Hospital Department of Radiation Oncology \\ ${ }^{2}$ Kayseri Training and Research Hospital Department of Pathology, Kayseri, TURKEY
}

\begin{abstract}
To investigate whether hormonotherapy followed by concomitant use of trastuzumab (T) and radiation therapy (RT) contributes to the development of radiation-induced skin fibrosis. 70 healthy female rats divided into seven groups: Control group (C) underwent no procedure. RT group underwent thoracic radiation (TR). T group was administered T. T+RT+Tx group was administered concomitant $T$ and TR, followed by tamoxifen. T+RT+Le group was administered concomitant $T$ and $T R$, followed by letrozole. $T+R T+A n$ group was administered concomitant $T$ and TR, followed by anastrazole. T+RT+Ex group was administered concomitant $T$ and TR, followed by exemestane. Trastuzumab was administered in $6 \mathrm{mg} / \mathrm{kg}$. TR was performed two hours after T administration. Hormonotherapy was given at one week following RT. Rats were sacrificed at 24 weeks. Skin was scored in histopathological examination. Skin inflammation was most commonly seen in the RT, $T+R T+T x$ and $T+R T+L e$ group. Skin fibrosis was present in all subjects exposed to RT. Control group, $T$ and $T+R T+E x$ group had the lowest vascular damage scores, while $R T, T+R T+T x$ and $T+R T+L$ e had the highest scores. The $R T, T+R T+T x$ and $T+R T+L e$ group had the highest muscular fibrosis scores. Muscular fibrosis was lesser in $T+R T+A n$ and $T+R T+E x$ group. The rate of vascular damage in muscular tissue was the highest in RT, $T+R T+T x$ and $T+R T+L e$ group. No vascular damage was observed in $T$ and $T+R T+E x$ group. Our study results suggested that tamoxifen and letrozole following concomitant use of T and RT increased skin fibrosis, while anastrazole and exemestane reduced radiation-induced skin fibrosis.
\end{abstract}

Key Words: Skin, Fibrosis, Radiation therapy,Trastuzumab, Hormonotherapy

\section{ÖZET}

Radyoterapi ile Eşzamanlı Trastuzumab Tedavisinden Sonra Verilen Hormonoterapinin Ciltte Gelişen Geç Toksisite Üzerine Etkisi

Radyoterapi ile eşzamanlı trastuzumab tedavisinden sonra verilen hormonoterapinin ciltte radyasyon fibrozisi gelişimine katkısı olup olmayacağını araştırmaktır. 70 adet erişkin sağlıkı sıçan, 7 gruba ayrıldı. K grup (Kontrol grubu); RT grubu (Sadece radyoterapi uygulanan); T grubu (Sadece trastuzumab verilen); T+RT+Tam grubu (RT ile eş zamanlı T verildikten sonra tamoksifen verilen grup); $T+R T+L e$ grubu (RT ile eş zamanlı T sonrası letrozol verilen); $T+R T+A n$ grubu (RT ile eş zamanlı T sonrası anastrazol verilen); $T+R T+E x$ grubu (RT ile eşzamanlı T sonrası exemestan) verilen grup olarak belirlendi. Trastuzumab, $6 \mathrm{mg} / \mathrm{kg}$ verildi. RT, T'den iki saat sonra, göğüs duvarına tek fraksiyonda ışınlama yapıldı. RT'den bir hafta sonra hormonoterapi ilaçları 6 ay süre ile verildi. 24 hafta sonra sıçanlar sakrifiye edildi. Deri dokusu histopatolojik olarak incelendi. Deride inflemasyon en fazla $R T, T+R T+T a m$ ve $T+R T+L$ gruplarında görüldü. $R T$ alan grupların hepsinde deride fibrosizin oluştuğu görüldü. Deride vasküler hasar skorlaması en düşük kontrol, T ve T+RT+Ex gruplarında en yüksek skorlama RT, T+RT+Tam ve $T+R T+L e$ gruplarında bulundu. Kasta fibrosiz skorlaması en yüksek $R T, T, T+R T+T a m, T+R T+L e$ gruplarında bulundu. $T+R T+A n$ and $T+R T+E x$ gruplarında kasta fibrozisin azaldığı görüldü. Kasta vasküler hasarın en fazla $R T, T+R T+L e$ ve $T+R T+T a m$ gruplarında oluştuğu görüldü. T ve T+RT+Ex'nın ise hasar yapmadığı görüldü. RT ile eşzamanlı T kullanımından sonra ardışık uygulanan tamoksifen ve letrozolün ciltte fibrozisi artırdığı görüldü. Anastrazol ve exemestanın radyasyon fibrozisini azalttığı görüldü.

Anahtar Kelimeler: Cilt, Fibrozis, Radyoterapi, Trastuzumab, Hormonoterapi 


\section{INTRODUCTION}

With the introduction of recent therapeutic developments in cancer, the success rate of complete recovery from breast cancer has been increasingly dominated. Currently, effective treatments offer a dramatic increase in the survival rates. However, prolonged survival usually results in increased incidence of treatment-related side effects. ${ }^{1}$

Skin problems are one of the most common treatment-related side effects in patients with breast cancer. Surgery, radiation therapy (RT), systemic therapy and characteristics of the patient may induce skin problems. $^{2-4}$

Radiation therapy induces the occurrence of oedema, inflammation and vascular dilatation, decreasing the basal epithelial cells and increasing the mitotic index in the acute stage. Increased acute reactions provide a ground path for post-recovery late reactions. Acute reactions typically develop depending on the uptitration at two or three weeks of conventional RT, while late reactions including skin fibrosis usually develop at six months up to three years following RT. Microvascular destructions following acute reactions often lead to telangiectasis, subcutaneous fibrosis, atrophy, hair follicle loss, ulceration and necrosis. Therefore, increased acute reactions are associated with postrecovery late reactions. ${ }^{4-6}$

Recent developments have resulted in the introduction of novel active chemotherapeutic agents such as trastuzumab $(\mathrm{T})$ and combination therapies with RT. Several complications of these chemotherapeutic agents, which can be largely reversible if early diagnosed, have been reported. Clinician may overlook several toxicities during their efforts focus on the management of major toxicities including myelosupression, diarrhea, and vomiting. However, toxicities which are overlooked by the clinician may result in irreversible complications. These toxicities may be related to drug, dose, cumulative dose or management approach. ${ }^{2,3,7}$

In addition, skin fibrosis is an aesthetic problem in patients with breast cancer. Aesthetic outcome of conservative treatment of early-stage breast cancer is also as critical as local control and survival, since good aesthetic outcome is the main goal of breastconserving therapy. Possible factors, which may statistically influence the aesthetic outcome of breastconserving therapy, include the width of resection, re-excision, orientation of incisions, total dose for whole breast, dose gradient within the breast, tumor bed boost, additional sites for peripheral lymphatic radiation, concomitant chemotherapy, tumor size and age of the patient. ${ }^{8,9}$

In this experimental study, we aimed to investigate whether hormonotherapy followed by concomitant use of T, a monoclonal antibody, and RT contributes to the development of radiation-induced skin fibrosis.

\section{MATERIALS AND METHODS}

\section{Experimental Animals and Study Procedure}

A total of 70 adult female Wistar Albino rats ( $n=10$ in each group) aged 8-12 weeks with a mean weight of $213 \pm 27 \mathrm{~g}$ were included. The rats were subjected to light for 12 hours and dark for 12 hours under laboratory conditions at $25 \pm 3^{\circ} \mathrm{C}$ and fed with commercial rat food. The study protocol was approved by the local Ethics Committee on Animal Experiments. Subjects were obtained from Erciyes University, Faculty of Medicine, Hakan Cetinsaya Experimental and Clinical Research Center.

Rats were randomly assigned into seven groups, including 10 in each group:

First group (C): underwent no procedure.

Second group (RT): underwent RT alone.

Third group (T): was administered $\mathrm{T}$ alone. $\mathrm{T}$ was administered IV push through tail vein. One week following radiation, distilled water was administered by oral gavage once daily for 6 months.

Fourth group (RT+T+Tx): was administered tamoxifen, followed by concomitant T and RT. Tamoxifen was melted in distilled water and administered by oral gavage once daily for 6 months.

Fifth group (RT+T+Le): was administered concomitant $\mathrm{T}$ and RT, followed by letrozole.

Sixth group $(\mathrm{T}+\mathrm{RT}+\mathrm{An})$ : was administered concomitant $\mathrm{T}$ and $\mathrm{RT}$, followed by anastrazole.

Seventh group $(\mathrm{T}+\mathrm{RT}+\mathrm{Ex})$ : was administered concomitant $\mathrm{T}$ and $\mathrm{RT}$, followed by exemestane.

Distilled water rather than $\mathrm{T}$ was injected through tail vein. Thoracic radiation was performed under anesthesia two hours later. One week following radiation, distilled water was administered by oral gavage once daily for 6 months.

Concomitant $\mathrm{T}$ and $\mathrm{RT}$ were administered to $\mathrm{T}+\mathrm{RT}+\mathrm{Le}, \mathrm{T}+\mathrm{RT}+\mathrm{An}$ and $\mathrm{T}+\mathrm{RT}+\mathrm{Exe}$ group, as indicated in $\mathrm{T}+\mathrm{RT}+\mathrm{Tx}$. Corresponding dosage was calculated based on the weight of each rat. Letrozole, anastrazole and exemestane were melted in distilled water and administered by oral gavage once daily for 
6 months. Distilled water alone was given to the T, RT and $\mathrm{C}$ group by oral gavage once daily for 6 months.

\section{Trastuzumab, Radiotherapy and Hormonothera- peutic Agents Administration}

$\mathrm{T}$ was initially administered. Trastuzumab (Herceptin) was supplied by Roche. Trastuzumab was administered in $6 \mathrm{mg} / \mathrm{kg}$, standard maintenance dose in human for three cycles. The rats were weighted before administration. Corresponding dosage was calculated based on the weight of each rat. The agent was melted in distilled water $(100 \mathrm{cc})$ and administered in $6 \mathrm{mg} /$ $\mathrm{kg}$ through tail vein.

At two hours following $\mathrm{T}$ administration, the rats were sedated under anesthesia with ketamine and four rats at a time were selected. The rats were positioned on the foam mechanism. The arms and legs were fixed in supine position. Simulation was performed including both lungs. The dose was administered as a sigle 12 Gy fraction at $2 \mathrm{~cm}$ depth and 64 SSD from the anterior region to the site of $5 \times 30 \mathrm{~cm}$ through Co- 60 (Theratron $780 \mathrm{C}$, Canada).

Considering the half-life of T, other therapies including tamoxifen, anastrazole, letrozole and exemestane were initiated at one week following RT. Tamoxifen (Tamoxifen-Teva) was supplied by Med-Ilac, anastrazole (Arimidex) by AstraZeneca, letrozole (Femara) by Novartis, and exemestane (Aromasin) by Pfizer. Equivalent doses of $20 \mathrm{mg}, 1 \mathrm{mg}, 2.5 \mathrm{mg}$ and $25 \mathrm{mg}$ of tamoxifen, anastrazole, letrozole and exemestane for an adult weighed $60 \mathrm{~kg}$ were respectively calculated for the rats weighed $200 \mathrm{~g}$. Drugs were melted in distilled water and administered by oral gavage once daily.

\section{Histopathological Examination}

The study was discontinued at 24 weeks. The rats were sedated under anesthesia and sacrificed. Thoracic site was dissected at $2 \times 2 \mathrm{~cm}$. Tissue samples were washed in iced isotonic saline solution and stored in a sterilized plate containing $10 \%$ formaldehyde for 24 hours. Serial sections at 5 micron obtained following paraffin blockage were stained with HematoxylinEosin and Masson's trichrome. Atrial, ventricular and vascular structures of the tissue samples were assessed using light microscope. Histopathological examination was performed using scoring system proposed by Gallet et al. ${ }^{10}$ The severity and score of skin and muscular fibrosis, inflammation, vascularity an cellular alterations were assessed in the pathological examination. The scoring range was 0 to 3 ( 0 : no injury, 1: mild injury, 2: moderate injury, 3 : severe injury.

\section{Statistical Analysis}

The statistical analysis was performed using SPSS (Statistical Package for Social Sciences for Windows) and SigmaStat v. 3.5 software. Shapiro-Wilks Normality test was conducted to test normality of the data. Kruskal-Wallis and Student-Newman-Keuls methods were done to compare variables. Quantitative variables were expressed in mean and median $(25$ to $75 \%$ ). A p value of $<0.05$ was considered statistically significant.

\section{RESULTS}

At the end of the study, no loss was seen in any group. Skin and muscular tissues were individually evaluated and scored in the histopathological examination. Skin alterations from baseline are summarized in Table 1. A statistically significant difference in skin inflammation, fibrosis and vascular damage scores was observed among the groups, while no significant difference in cellular skin alterations was seen. Skin inflammation was most commonly seen in the RT, T+RT+Tx and T+RT+Le group (Figure 1a,b,c). $\mathrm{T}$ and $\mathrm{T}+\mathrm{RT}+\mathrm{Ex}$ group had the lowest scores of skin inflammation. There was a statistically significant difference in skin inflammation among RT, $\mathrm{C}$ and $\mathrm{T}+\mathrm{RT}+\mathrm{Ex}$ group, $\mathrm{T}+\mathrm{RT}+\mathrm{Le}, \mathrm{C}$ and $\mathrm{T}+\mathrm{RT}+\mathrm{Ex}$ group, $\mathrm{T}+\mathrm{RT}+\mathrm{Tx}, \mathrm{C}$ and $\mathrm{T}+\mathrm{RT}+\mathrm{Ex}$ group $(\mathrm{p}<0.05)$ (Figure $2 a, b, c)$.

Skin fibrosis was present in all subjects exposed to RT. There was a significant difference in skin fibrosis between the control group and other groups $(\mathrm{p}<$ $0.05)$. Control group had the lowest vascular damage scores, while RT, $\mathrm{T}+\mathrm{RT}+\mathrm{Tx}$ and $\mathrm{T}+\mathrm{RT}+\mathrm{Le}$ had the highest scores, indicating a significant difference.

The median scores of muscular tissues (25 to $75 \%$ ) are shown in Table 2. There was no significant difference in cellular alterations in the muscular tissue and inflammation among the groups ( $>>0.05)$. The $\mathrm{RT}, \mathrm{T}+\mathrm{RT}+\mathrm{Tx}$ and $\mathrm{T}+\mathrm{RT}+\mathrm{Le}$ group had the highest muscular fibrosis scores, whereas $\mathrm{C}, \mathrm{T}+\mathrm{RT}+\mathrm{Ex}$ and $\mathrm{T}+\mathrm{RT}+\mathrm{An}$ group had the lowest scores (Figure 3a, b). Muscular fibrosis was lesser in $\mathrm{T}+\mathrm{RT}+\mathrm{An}$ and $\mathrm{T}+\mathrm{RT}+\mathrm{Ex}$ group. There was a statistically signifi- 
International Journal of Hematology and Oncology

\begin{tabular}{|c|c|c|c|c|c|c|c|c|}
\hline $\begin{array}{l}\text { Skin } \\
\text { Tissue }\end{array}$ & $\begin{array}{l}\text { C Group } \\
\text { Median } \\
(25 \%-75 \%)\end{array}$ & $\begin{array}{l}\text { RT Group } \\
\text { Median } \\
(25 \%-75 \%)\end{array}$ & $\begin{array}{l}\text { T Group } \\
\text { Median } \\
(25 \%-75 \%)\end{array}$ & $\begin{array}{l}\text { T+RT+Tx Group } \\
\text { Median } \\
(25 \%-75 \%)\end{array}$ & $\begin{array}{l}\text { T+RT+Le Group } \\
\text { Median } \\
(25 \%-75 \%)\end{array}$ & $\begin{array}{l}\text { T+RT+An Group } \\
\text { Median } \\
(25 \%-75 \%)\end{array}$ & $\begin{array}{l}\text { T+RT+Exe } \\
\text { Group Median } \\
(25 \%-75 \%)\end{array}$ & $\begin{array}{l}p \\
(p<0.05)\end{array}$ \\
\hline Inflammation & $0.0(0.0-0.0)$ & $1.0(1.0-1.0)$ & $0.0(0.0-1.0)$ & $1.0(0.0-1.0)$ & $1.0(1.0-1.0)$ & $0.0(0.0-1.0)$ & $0.0(0.0-0.0)$ & $\begin{array}{c}5-1,5-7 \\
2-1,2-7 \\
4-1,4-7 \\
3-1,6-1 \\
7-1\end{array}$ \\
\hline Fibrosis & $0.0(0.0-0.0)$ & $1.0(1.0-1.0)$ & $1.0(1.0-1.0)$ & $1.0(1.0-1.0)$ & $1.0(1.0-1.0)$ & $1.0(0.0-1.0)$ & $1.0(0.0-1.0)$ & $\begin{array}{l}4-1,5-1 \\
2-1,3-1 \\
6-1,7-1\end{array}$ \\
\hline Vascularity & $0.0(0.0-0.0)$ & $1.0(1.0-1.0)$ & $0.0(0.0-0.0)$ & $1.0(1.0-1.0)$ & $1.0(1.0-1.0)$ & $0.5(0.0-1.0)$ & $0.0(0.0-0.0)$ & $\begin{array}{l}5-7,5-3, \\
5-1,5-6, \\
2-7,2-3, \\
2-1,2-6, \\
4-7,4-3, \\
4-1,4-6, \\
4-7,6-3, \\
6-1\end{array}$ \\
\hline $\begin{array}{l}\text { Cellular } \\
\text { alterations }\end{array}$ & $0.0(0.0-0.0)$ & $0.0(0.0-0.0)$ & $0.0(0.0-0.0)$ & $0.0(0.0-0.0)$ & $0.0(0.0-1.0)$ & $0.0(0.0-0.0)$ & $0.0(0.0-0.0)$ & - \\
\hline
\end{tabular}

"1234567: The groups in the same column with different numbers are statistically significant $(p<0.05)$ "

cant difference in muscular fibrosis among RT, $\mathrm{C}$ and $\mathrm{T}+\mathrm{RT}+\mathrm{Ex}$ group, $\mathrm{T}+\mathrm{RT}+\mathrm{Tx}, \mathrm{C}$ and $\mathrm{T}+\mathrm{RT}+\mathrm{Ex}$ group, $\mathrm{T}+\mathrm{RT}+\mathrm{Le}, \mathrm{C}$ and $\mathrm{T}+\mathrm{RT}+\mathrm{Ex}$ group, and $\mathrm{T}+\mathrm{RT}+\mathrm{An}, \mathrm{C}$ and $\mathrm{T}+\mathrm{RT}+\mathrm{Ex}$ group $(\mathrm{p}<0.05)$.

The rate of vascular damage in the muscular tissue was the highest in $\mathrm{RT}, \mathrm{T}+\mathrm{RT}+\mathrm{Tx}$ and $\mathrm{T}+\mathrm{RT}+\mathrm{Le}$ group. No vascular damage was observed in $\mathrm{T}$ and $\mathrm{T}+\mathrm{RT}+\mathrm{Ex}$ group. There was a statistically significant difference in vascular damage among RT, C, T, $\mathrm{T}+\mathrm{RT}+\mathrm{Le}$ and $\mathrm{T}+\mathrm{RT}+\mathrm{Ex}$ group. There was also a significant difference in the scores of vascular damage among $\mathrm{T}+\mathrm{RT}+\mathrm{Tx}, \mathrm{C}, \mathrm{T}, \mathrm{T}+\mathrm{RT}+\mathrm{Ex}$ group, $\mathrm{T}+\mathrm{RT}+\mathrm{Le}$, $\mathrm{C}, \mathrm{T}$ and $\mathrm{T}+\mathrm{RT}+$ Ex group.

\section{DISCUSSION}

In parallel to recent developments in breast cancer therapeutics, the efficacy of oncological management modalities has been increasing. However, this has resulted in an increased trend of treatment-related side effects. ${ }^{1}$ As a result, application of RT doses for tumors and healthy tissues in patients undergoing concomitant or subsequent RT and chemotherapy has been revisited.

Radiation-induced dermatitis has been well-known since X-ray was discovered by Wilhelm Roentgen in $1895 .^{4,5}$ The skin is primarily affected, although several tissues and organs are affected by radiation. Radiation therapy-related side effects are the most common side effects of RT and can be dose-limiting. . $^{3,12}$

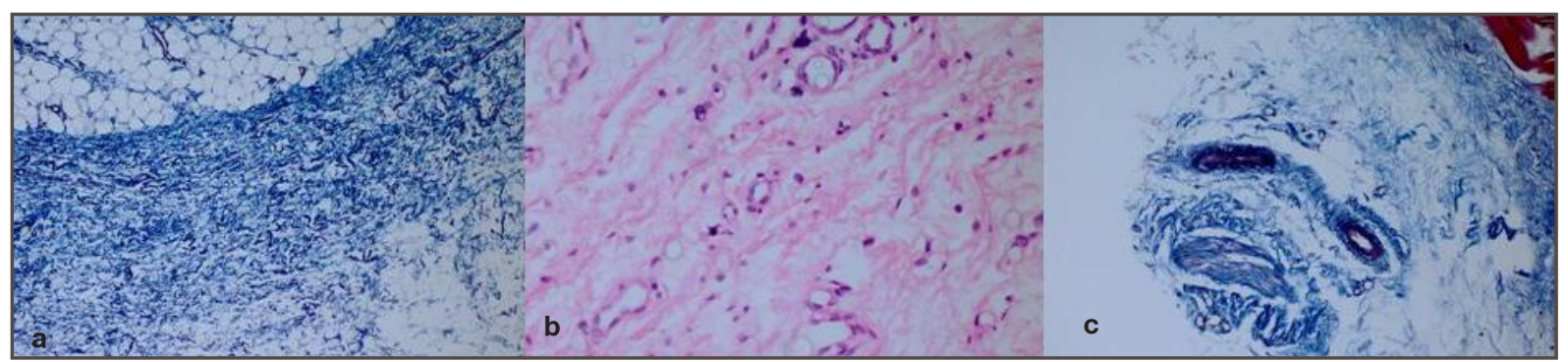

Figure 1a, b, c. Tamoxifen and letrozole groups increased score of inflammation, vascular damage and fibrosis in skin tissue (Masson's trichrome, H\&E, x 200). 
International Journal of Hematology and Oncology

\begin{tabular}{|c|c|c|c|c|c|c|c|c|}
\hline $\begin{array}{l}\text { Skin } \\
\text { Tissue }\end{array}$ & $\begin{array}{l}\text { C Group } \\
\text { Median } \\
(25 \%-75 \%)\end{array}$ & $\begin{array}{l}\text { RT Group } \\
\text { Median } \\
(25 \%-75 \%)\end{array}$ & $\begin{array}{l}\text { T Group } \\
\text { Median } \\
(25 \%-75 \%)\end{array}$ & $\begin{array}{l}\text { T+RT+Tx Group } \\
\text { Median } \\
(25 \%-75 \%)\end{array}$ & $\begin{array}{l}\text { T+RT+Le Group } \\
\text { Median } \\
(25 \%-75 \%)\end{array}$ & $\begin{array}{l}\text { T+RT+An Group } \\
\text { Median } \\
(25 \%-75 \%)\end{array}$ & $\begin{array}{l}\text { T+RT+Exe } \\
\text { Group Median } \\
(25 \%-75 \%)\end{array}$ & $\begin{array}{l}p \\
(p<0.05)\end{array}$ \\
\hline Inflammation & $0.0(0.0-0.0)$ & $0.0(0.0-0.0)$ & $0.0(0.0-0.0)$ & $0.0(0.0-0.0)$ & $0.0(0.0-1.0)$ & $0.0(0.0-0.0)$ & $0.0(0.0-0.0)$ & - \\
\hline Fibrosis & $0.0(0.0-0.0)$ & $1.0(1.0-1.0)$ & $1.0(1.0-1.0)$ & $1.0(1.0-1.0)$ & $1.0(1.0-1.0)$ & $0.5(0.0-1.0)$ & $0.0(0.0-0.0)$ & $\begin{array}{c}\text { 4-7, 4-1, } \\
5-7,5-1 \\
2-7,2-1 \\
3-7,3-1 \\
6-7,6-1\end{array}$ \\
\hline Vascularity & $0.0(0.0-0.0)$ & $1.0(1.0-1.0)$ & $0.0(0.0-0.0)$ & $1.0(1.0-1.0)$ & $1.0(1.0-1.0)$ & 0.5 (0.0-1.0) & $0.0(0.0-0.0)$ & $\begin{array}{l}\text { 5-7, 5-3, } \\
5-1,5-6, \\
2-7,2-3 \\
2-1,2-6 \\
4-7,4-3 \\
4-1,4-6 \\
4-7,6-1\end{array}$ \\
\hline Cellular & $0.0(0.0-0.0)$ & $0.0(0.0-0.0)$ & $0.0(0.0-0.0)$ & $1.0(0.0-1.0)$ & $0.0(0.0-1.0)$ & $0.0(0.0-0.0)$ & $0.0(0.0-0.0)$ & - \\
\hline
\end{tabular}

As breast tissues are affected by radiation, late side effects may occur. Although the incidence of such reactions is lower using the linear energy linear accelerators today thanks to the skin protective barrier rather than orthovoltage and cobalt machines, treatment-related late side effects are still a common problem. Late side effects following RT are primarily assessed based on normal-dose-volume principle. Daily RT dose, RT scheme, total duration of treatment and characteristics of organs are the major factors to identify these side effects. The size of RT site is also important as RT dose. Concomitant use of RT and other therapeutics increases these reactions. ${ }^{3,7,12-17,18}$

The incidence of moderate and severe fibrosis and retraction is up to $10 \%$ in patients with early-stage breast cancer undergoing breast-conserving surgery and RT. ${ }^{15}$ Oncologists from Washington University, Faculty of Medicine thoroughly reviewed possible factors influencing aesthetic outcome of breast-conserving therapy. They found that the success rate of breast radiation was reduced from $43 \%$ to $31 \%$ when supraventricular and axillary lymphatic sites were additionally exposed. A total of 45-50 Gy radiation dose resulted in an excellent aesthetic outcome in $43 \%$ of the patients and a good aesthetic outcome in $46 \%$ of the patients. On the other hand, a total of $\geq 50$ Gy radiation dose resulted in an excellent aesthetic outcome in 28 of the patients $(\mathrm{p}=0.02)$. Multivariate analysis revealed that possible factors influencing an excellent aesthetic outcome of RT included the width of resection, the race of the patient, total dose for whole breast and age of the patient, respectively. ${ }^{18}$

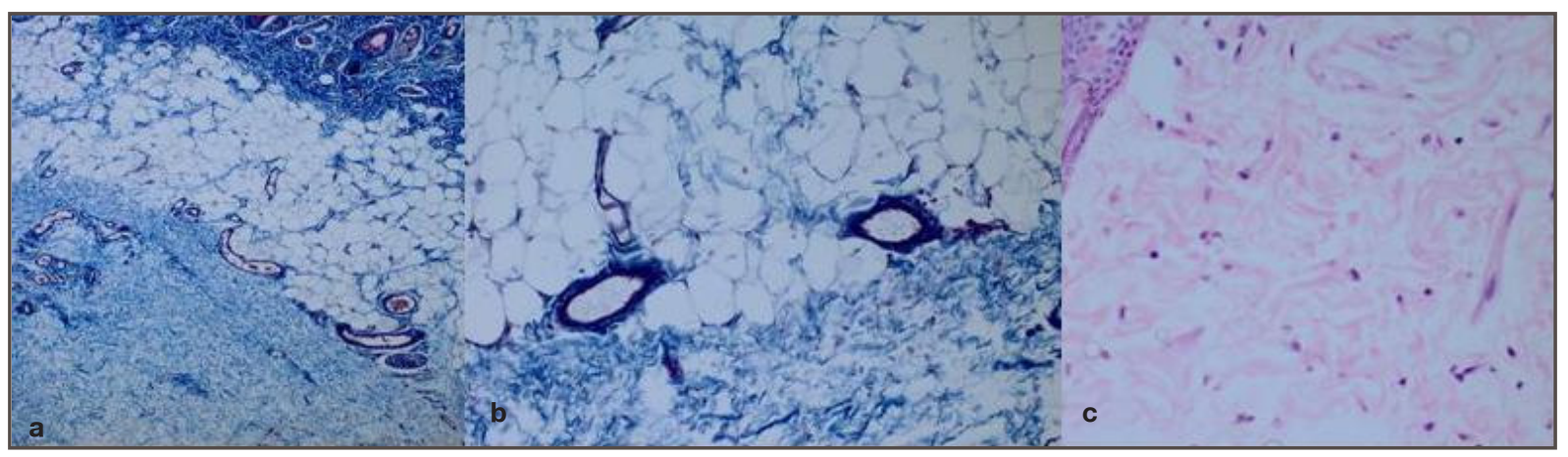

Figure 2a, b, c. Anastrazole and exemestane reduced severity in skin and musculer tissues. (Masson's trichrome, H\&E, x200). 


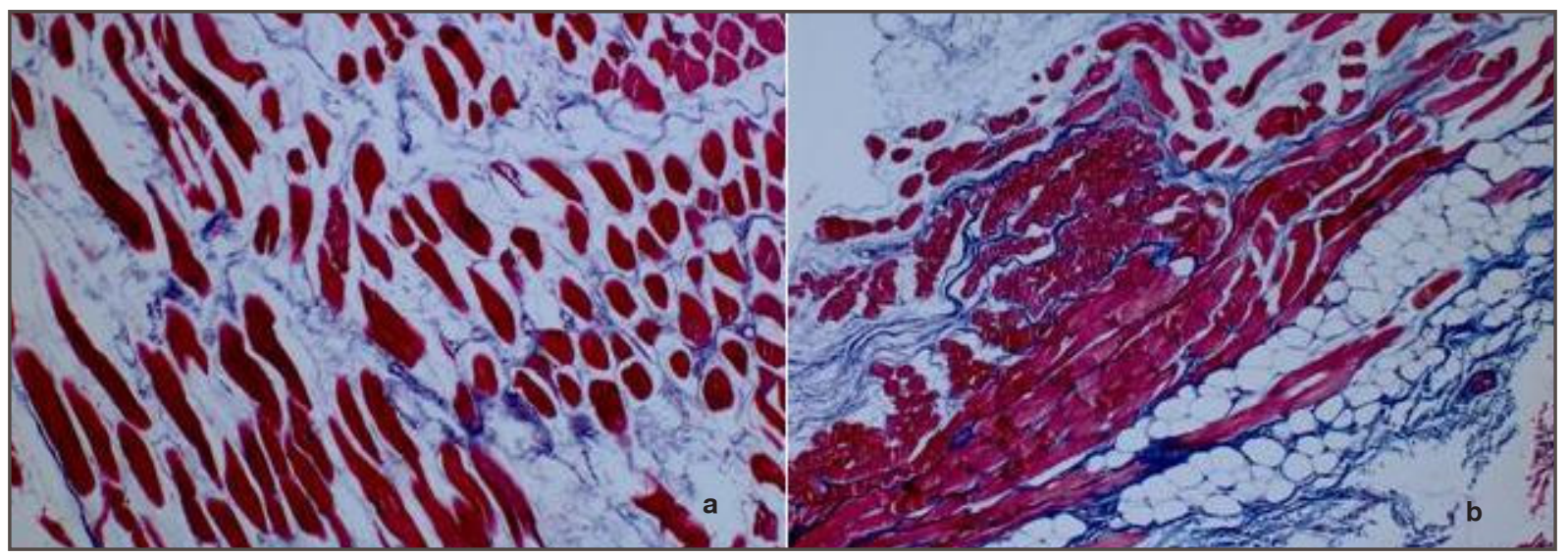

Figure 3a, b. $R T+T+T x, R T+T+E x$ groups musculer tissue (Masson's trichrome, $x$ 200)

In our study, we assessed the hormonotherapy-related late side effects in the skin following concomitant $\mathrm{T}$ and RT. We found a significant difference in skin and muscular fibrosis and vascular damage scores among the groups. Skin fibrosis was also present in all subjects exposed to RT. Skin fibrosis was also present in $\mathrm{T}$ group to a lesser extent that of RT group.

In recent years, targeted therapies for breast cancer have been introduced. Trastuzumab (T, Herceptin, Roche) is a recombinant monoclonal antibody against human epithelial receptor type 2 (HER2). As an adjunctive therapy, it has beneficial effects on diseasefree survival in patients with HER2/neu-positive in both node-negative and node-positive breast cancer., ${ }^{2,7-9,12,14}$ Thus, $\mathrm{T}$ is typically combined with RT currently. However, the combination therapy-related side effects in the long-term remains to be elucidated with a limited number of reports. In the FinHER study, the authors reported that concomitant use of $\mathrm{T}$ and RT on a weekly basis offered prolonged disease-free survival, while increased acute skin toxicities. ${ }^{19}$ In a review, however, Raben, Horton ${ }^{7}$, Belkacemi $^{8}$ and Perez[2] reported that concomitant use of $\mathrm{T}$ and RT did not increase the early skin complications. On the other hand, in NCCTG N983 1 study, Perez et al. ${ }^{2}$ reported that concomitant use of $\mathrm{T}$ and RT on a weekly basis was an independent prognostic factor for dermatitis (Grade $\geq 2$ ). The authors found that concomitant use of T and RT on a weekly basis increased the skin toxicity, compared to trastuzumab administration for three weeks. On the other hand, Halyard et al. ${ }^{20}$ conducted a retrospective study (North Central Cancer Group Phase III trial) in patients with breast cancer and compared two groups exposing $(n=908)$ or not exposing to RT ( $\mathrm{n}=308)$. The authors found that concomitant use of T and RT did not increase side effects in the skin at the end of a-18-month follow-up. Similarly, Raben et al.showed that there was no significant difference in acute toxicities involving the chest or breast, including edema and skin reaction, among the patients undergoing concomitant use of $\mathrm{T}$ and RT or external RT alone.

Review of literature has revealed controversial data on the incidence of acute toxicities of the skin through concomitant or subsequent use of $\mathrm{T}$ and RT. It is well-established that increased acute reactions lead to post-recovery late reactions. In our study, we also observed that $\mathrm{T}$ alone increased skin fibrosis slightly compared to the control group. However, we did not found any increase in the skin toxicities when $\mathrm{T}$ was administered in combination with RT. On the other hand, Belkacemi et al. ${ }^{8}$ administered concomitant $\mathrm{T}$ and RT to 146 patients with early-stage breast cancer and observed Grade 2 dermatitis in $51 \%$ of the patients, associated with the menopausal status of the patients as well as T dose. Bellon et al. ${ }^{7}$ also reported that Grade 3 skin toxicity was observed in $8 \%$ of 26 patients with early-stage breast cancer when $\mathrm{T}$ was used in combination with RT.

In our study, RT, tamoxifen and letrozole group had the highest score of inflammation, vascular damage and fibrosis. We observed that anastrazole and exemestane reduced the severity of fibrosis. In addition, Azria et al. ${ }^{21}$ evaluated the efficacy of RT concomitant or subsequent with letrozole. Letrozole treatment was initiated at three weeks before RT in concomitant group and at three weeks after RT in subsequent group. A 50 Gy dose was applied at 6-18 
MV using three-dimensional conformal therapy with a mean follow-up of 24 months. The authors observed subcutaneous fibrosis at 14 months. They also reported that there was no significant difference in skin reactions at 24 months. Similarly, Valakh et al. ${ }^{22}$ administered RT concomitant or subsequent with anastrazole in postmenopausal patients with breast cancer with equivalent comorbidity rate as well as similar tumor size and hormonal receptor ratio. The authors found that concomitant use of RT and anastrazole did not increase acute or late complication rate. They also reported that tamoxifen in combination with RT increased radiation-induced subcutaneous fibrosis. ${ }^{23,24}$ In conclusion, our study results showed that $\mathrm{T}$ administration alone resulted in skin fibrosis, compared to the control group. Additionally, tamoxifen and letrozole following concomitant use of T and RT increased skin fibrosis, while anastrazole and exemestane reduced radiation-induced skin fibrosis. Further large-scale clinical trials are required to provide a better understanding of using targeted therapies including trastuzumab.

\section{REFERENCES}

1. Hewitt M, Greenfield S, Stovall E. From cancer patient to cancer survivor: lost in transition. National Academies Press, Washington (DC), 2005: 250.

2. Perez EA, Romond EH, Suman VJ, et al. Updated results of the combined analysis of NCCTG N9831 and NSABP B31adjuvant chemotherapy with/without trastuzumab in patients with HER2-positive breast cancer. Proc ASCO 2007; 25: 512.

3. Raj KA, Marks LB, Prosnitz RG. Late effects of breast radiotherapy in young women. Breast Dis 23: 53-65, 2005.

4. Ertekin MV, Tekin SB, Erdogan F, et al. The effect of zinc sulphate in the prevention of radiation-induced dermatitis. $J$ Rad Res 45: 543-548, 2004.

5. Bernstein EF, Sullivan FJ, Mitchell JB, Salomon GD, Glatstein E. Biology of chronic radiation effect on tissues and wound healing. Clin Plast Surg 20: 435-453, 1993.

6. Murakami R, Baba Y, Nishimura R, et al. The effect of azelastine on acute radiation dermatitis in mice models. J Rad Onc Biol Phys 37: 907-911, 1997.

7. Bellon JR, Gover MT, Burnstein HJ. Concurrent trastuzumab and radiation therapy in the adjuvant treatment of breast cancer. Int J Radiat Oncol Biol Phys 63: 55-56, 2005.

8. Belkacemi Y, Gligorov J, Ozsahin M, et al. Concurrent of trastuzumab with adjuvant radiotherapy in Her2-positive breast cancer patients: acute toxicity analyses from the French multicentric study. Ann Oncol 19: 1110-1116, 2008.
9. Perez EA, Halyard A, Pisansky T, et al. Radiotherapy concurrent with trastuzumab is well tolerated in the adjuvant treatment of women with HER-2 positive breast cancer: cardiac safety data from the NCCTG N9831 study. Eur J Cancer Suppl 4: 113, 2006.

10. Gallet P, Phulpin B, Merlim JL, et al. Long-term alterations of cytokines and growth factors expression in irradiated tissues and relation with histological severity scoring. PLoS One 6: e28399, 2011.

11. Horton JK, Sherron RF, Moore DT, et al. Phase I/II trial of herceptin plus radiotherapyfor chemotherapy-refractory locally advanced or recurrent breast cancer. Int $\mathrm{J}$ of Radiat Oncol Biol Phys 66: 220-221, 2006.

12. Koukourakis MI, Manavis J, Simopoulos C, et al. Hypofractionated accelerated radiotherapy with cytoprotection combined with trastuzumab, doxorubicine, and doxataxel in cerbB-2-positive breast cancer. Am J Clin Oncol 28: 495-500, 2005.

13. Valabrega G, Danese S, Vietti-Ramus G, et al. Outcome of patients with HER2-positive advanced breast cancer progressing during trastuzumab-based therapy. Oncologist 11: 318-324, 2006.

14. Schmidt-Ulrich R, Wazer DE, Tercilla O, et al. Tumor margin assesment as a guide to optimal conservation surgery and irradaiation in early breast carcinoma. Int J Radiat Oncol Biol Phys 17: 733-738, 1989.

15. Bedwinek J, Perez C, Kramer $\mathrm{S}$ et al. Irradiation sa the primary manegement of stage I and II adenocarcinoma of the breast. Cancer Clin Trials 3: 11-16, 1980.

16. Bentzen SM, Yarnold JR. Reports of unexpected late side effects of accelerated partial breast irradiation-radiobiological considerations. Int J Radiation Oncology Biol Phys 77: 969973, 2010.

17. Yarnold J, Vozenin Brotons MC. Pathogenetic mechanisms in radiation fibrosis. Radiother Oncol 97: 149-161, 2010.

18. Taylor Me, Perez CA, Halverson KJ, et al. Factors influencing cosmetic results after conservation therapy for breast cancer. Int J Radiat Oncol Biol Phys 31: 753-764, 1995.

19. Joensuu H, Kellokumpu-Lehtinen PL, et al. Adjuvant docetaxel or vinorelbine with or without trastuzumab for breast cancer. N Engl J Med 354: 809-820, 2006.

20. Halyard MY, Pisansky TM, Dueck AC, et al. Radiotherapy and adjuvant trastuzumab in operable breast cancer: tolerability and adverse event data from the NCCTG Phase III Trial N9831. J Clin Oncol 27: 2638-2644, 2009.

21. Azria D, Gourgou S, Sozzi WJ, et al. Concomitant use of tamoxifen with radiotherapy enhances subcutaneous breast fibrosis in hypersensitive patients. Brit J Cancer 91: 12511260, 2004.

22. Valakh V, Trombetta M, Werts ED, et al. Influence of concurrent anastrozole on acute and late side effects of whole breast radiotherapy. Am J Clin Oncol 34: 245-248, 2010.

23. Wazer DE, Morr J, Erban JK, et al. The effects of postradiation treatment with tamoxifen on local control and cosmetic outcome in the conservatively treated breast. Cancer 80: 732-740, 1997. 
International Journal of Hematology and Oncology

24. Fowble B, Fein DA, Hanlon AL, et al. The impact of tamoxifen on breast recurrence, cosmesis, complications, and survival in estrogen receptorpositive early-stage breast cancer. Int $\mathrm{J}$ Radiat Oncol Biol Phys 35: 669-677, 1996.

\section{Correspondence}

Dr. Yasemin BENDERLI CiHAN

Kayseri Eğitim ve Araştırma Hastanesi

Radyasyon Onkolojisi Bölümü

38010 Kocasinan, KAYSERI / TURKEY

KAYSERI

Tel: (+90. 3523368884 / Ext. 1922

Fax: (+90. 3523207313

e-mail: cihany@erciyes.edu.tr 